\title{
Rethink Everything 3: Markets, Globalization, Development
}

Nikhilesh Dholakia

University of Rhode Island

Deniz Atik

University of Texas Rio Grande Valley

Follow this and additional works at: https://digitalcommons.uri.edu/mgdr

Part of the Anthropology Commons, Economics Commons, Marketing Commons, Other Business Commons, and the Sociology Commons

\section{Recommended Citation}

Dholakia, Nikhilesh and Atik, Deniz (2020) "Rethink Everything 3: Markets, Globalization, Development," Markets, Globalization \& Development Review. Vol. 5: No. 4, Article 1.

DOI: 10.23860/MGDR-2020-05-04-01

Available at: https://digitalcommons.uri.edu/mgdr/vol5/iss4/1

This Editorial is brought to you for free and open access by DigitalCommons@URI. It has been accepted for inclusion in Markets, Globalization \& Development Review by an authorized editor of DigitalCommons@URI. For more information, please contact digitalcommons-group@uri.edu. 
Rethink Everything 3: Markets, Globalization, Development

\section{Markets, Globalization \& Development Review}
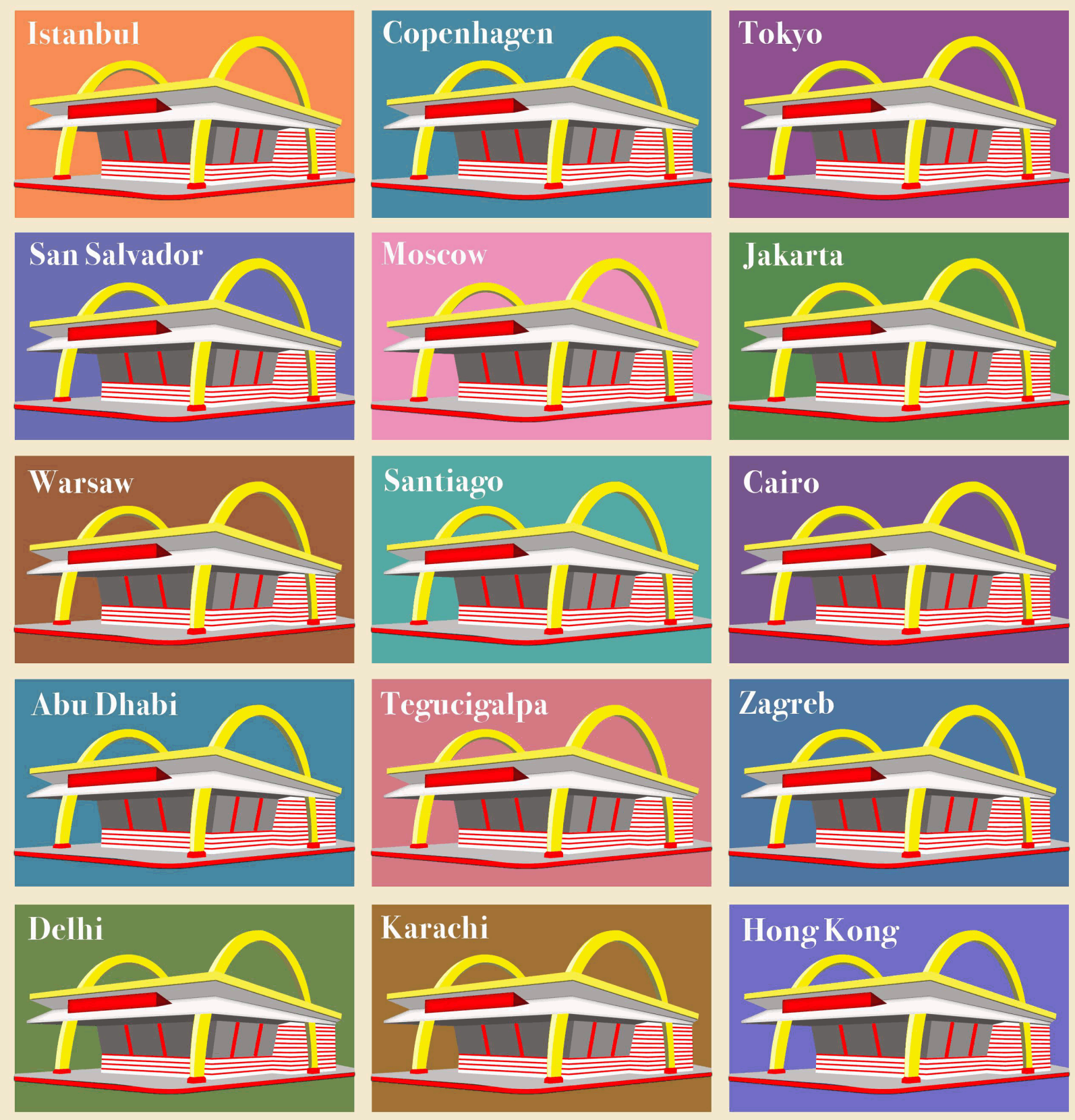

This editorial is available in Markets, Globalization \& Development Review: https://digitalcommons.uri.edu/mgdr/ vol5/iss $4 / 1$ 


\section{Rethink Everything 3: Markets, Globalization, Development}

\section{Introduction}

In two previous issues of MGDR, Numbers 1 and 3 of Volume 5, we launched explorations of how the very foundations of this journal - and indeed of the entire geopolitical and sociocultural global system - are being affected by the global COVID-19 pandemic. In these two issues, there were multifaceted insights regarding how the pandemic has changed, continues to change, and may change even more various aspects of our lifeworlds: consumption and consumers, markets and supply chains, technologies and media, the sociopolitical ethos, popular culture, and more (Cambefort 2020; Dholakia and Atik 2020a, 2020b; Hong 2020; Karanfil 2020; Kwet 2020; Mizukoshi and Hidaka 2020; Ozgun 2020; Ulusoy 2020; Vicdan 2020).

We continue this important exploration. Before presenting a preview of what this issue has to offer, we want to reflect - in a broad frame - the meta-knowledge that seems to emerge from the contributing authors to MGDR as well as from other researchers and analysts probing the impacts of this pandemic. In essence, the fast-emerging knowledge - in the social sciences and humanities - is pointing to the spectrum of impacts that could range from very Regressive to considerably Ameliorative, and all possibilities in-between. The impacts could take techno-economic, politico-cultural, and socio-communal forms - and of course spill across these categories. This creates the dimensional space for post-pandemic scenarios outlined in Figure 1.

Figure 1: The Dimensional Space for Post-Pandemic Scenarios

\begin{tabular}{|c|c|}
\hline \multirow[t]{2}{*}{ Forms } & Spectrum of Impacts - Humanity and Ecology \\
\hline & 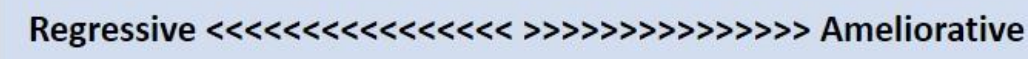 \\
\hline $\begin{array}{l}\text { Techno- } \\
\text { Economic }\end{array}$ & \\
\hline $\begin{array}{l}\text { Politico- } \\
\text { Cultural }\end{array}$ & \\
\hline $\begin{array}{l}\text { Socio- } \\
\text { Communal }\end{array}$ & \\
\hline
\end{tabular}


It is also becoming evident - for example in the scenarios outlined in the detailed table in our editorial in Volume 5, Number 3 - that there is divergence in the ways that analytical and reflective writers foresee the post-pandemic future (Dholakia and Atik 2020b). We capture the three broad categories of future scenarios in Figure 2. Some see a regressive future darker than the immediate pre-pandemic phase, others hope for a brightly optimistic turn for humanity and ecology, and yet others foresee a reverting to some type of status quo ante.

\section{Figure 2: Three Broad Types of Post-Pandemic Scenarios}

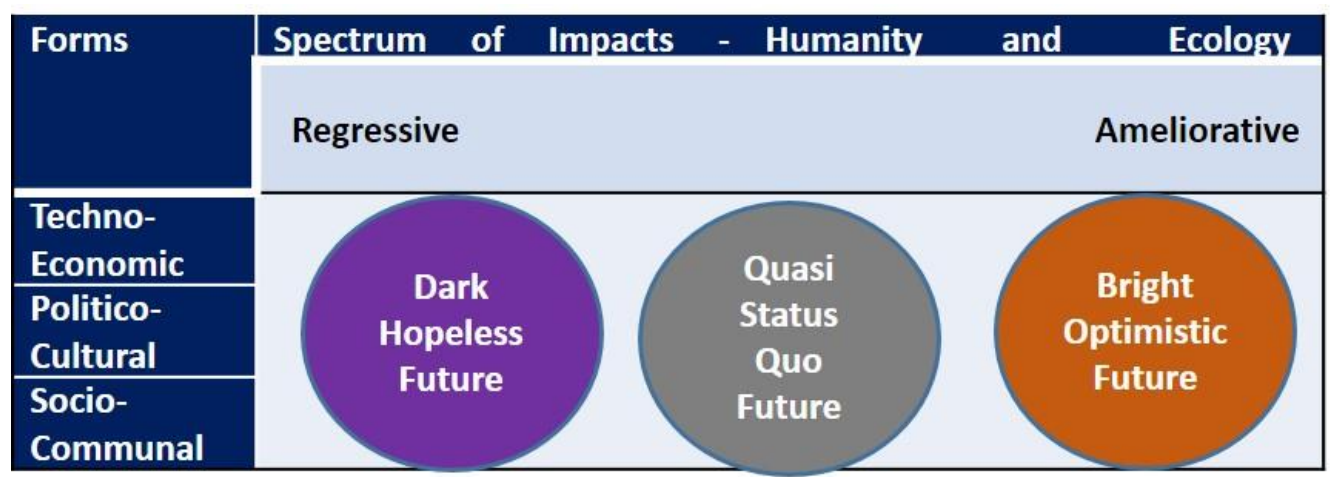

On further reflection, it strikes us that the forces that could propel the post-pandemic scenarios could be skewed. The forces that push toward the ameliorative end of the spectrum, on techno-economic dimensions, seem to be clearly stronger at this point. Technological advances did not slow down much during the pandemic, and likely accelerated in some fields such as communications methods and biotechnology. Furthermore, in regions where post-pandemic recovery has been underway or imminent, economic advances - especially gains in values of assets owned by the well-off segments - continued apace during the pandemic. On the politico-cultural and socio-communal fronts, however, there are few signs of ameliorative movement, and sometimes there are indicators of forces propelling the state of affairs toward the regressive end of the spectrum (see Figure 3). This, in our view, could give rise to future scenarios where techno-economic advancements, especially those benefiting the well-endowed and the well-off, would keep happening while politico-cultural and socio-communal conditions those affecting the daily lives of vast majority of humanity - could stagnate or even worsen (as pointed out in the review of the film Elysium in Volume 5, Number 3; see Ulusoy 2020). At MGDR, we want to encourage work that will move our world towards the ameliorative direction on all dimensions, and not just the techno-economic ones. And by 'work', we are of course referring to research and analytical work - of course, academic journals exist for this reason - but also to work in 
terms of policies and actions at all levels: macro (governmental and intergovernmental), meso (corporate entities and nonprofit organizations), and micro (groups, communities and individuals).

Figure 3: The Likely Thrust of Scenario-propelling Forces

\begin{tabular}{|l|lr|}
\hline Forms & Spectrum of Impacts - Humanity and & Ecology \\
& Regressive & Ameliorative \\
\hline $\begin{array}{l}\text { Techno- } \\
\text { Economic }\end{array}$ & & Ameliorative Techno-ronic Trends \\
\hline $\begin{array}{l}\text { Politico- } \\
\text { Cultural }\end{array}$ & Regressive Socio- & \\
\hline $\begin{array}{l}\text { Socio- } \\
\text { Communal }\end{array}$ & Political Trends & \\
\hline
\end{tabular}

\section{Article in this Issue}

The first and only article in this last issue of MGDR in 2020, still concerned with the global impact of the pandemic, Lemos et. al. (2020) examines Flexible and Autonomous Manufacturing Systems for Custom-Designed Products (FASTEN) as a potential solution for supply chain vulnerabilities in a time of crisis. In the case of Brazil and globally, COVID-19 pandemic caused an unanticipated demand for hospital safety items such as the face shields for health care professionals. The authors assert that "disruptions in the flows of production, movement and transportation of materials, financial flows and information flows, require greater information sharing, coordination and collaboration between participants, to ensure the continuity of operations (p. 10)," and FASTEN platform is adaptable to these disruptions in the market and enables the continuity of such operations and coordination in the supply chain. According to the authors, as a Smart Manufacturing System Project, FASTEN enables flexibility, improves production efficiency, and decreases costs. As MGDR editors, we welcome the optimistic note struck by this article. This note of optimism, clearly, is along the techno-economic dimension of Figure 3. In MGDR, we would like to see explorations of these issues - supply chain reconfigurations, automation, etc. - along the politico-cultural and socio-communal dimensions as well.

\section{Dialogues in this Issue}

In the first dialogue contribution of this issue, Harwood (2020) argues that "our understanding of ourselves and our relationship with others - 
other nations, other species, other worlds (p.2)" has been challenged during the pandemic. She explores if our transition into the posthuman is complete through a review of the book by Francesca Ferrando (2019), Philosophical Posthumanism. In this inquiry, from a philosophical perspective, "post-humanism refers to an understanding of the plurality of human-kind experiences (p.6)," including animal, machine or object. Fernando argues that posthumanity is a more inclusive term than humanity that "was mainly developed by free male intellectuals rather than including peripheral categories of human" (Harwood 2020, p.8). In her concluding remarks, Harwood (2020) claims "whilst we are posthuman through a multitude of different lenses, our transition is incomplete" (p.18) because in our market-based system, the 'us-other' dualism still conquers, and "technology may yet be the binding organ that helps us reconfigure globalized markets to achieve equality and balance for a sustainable environment" (p.18). In the framework of Figure 3, Harwood clearly has evoked all dimensions - and expresses some wariness, tempered with a touch of optimism, about the continuing dominance of the techno-economic dimension.

Going further, in the second commentary of this issue, Chikhi (2020) discuses the impact of the COVID-19 pandemic on the consumption behavior of Algerian citizens who have been hit hard by the rising unemployment rate. He draws attention to the changing consumption practices especially for food at the beginning of the COVID-19 alert. The author argues that, besides disturbing the consumption habits, the pandemic also resulted in some positive changes associated with consumption in general such as "the reduction in food waste, the sharp increase in orders and purchases over the Internet (long awaited by electronic platforms), the increase in the consumption of local products, and finally, the increase in domestic savings" (p.7). Chikhi questions whether and how such positive changes in consumer behavior can be sustainable in the future.

In the final dialogue of this issue, Takemura (2020) explores if there are any lessons to be learned from the Japanese way of dealing with the COVID-19 pandemic, which, at times, seemed to be more effective when compared to others. The author specifically emphasizes the "flip-flop" attitude of Japanese people toward changing conditions. To illustrate this, he compares the Japanese social response to COVID-19 to the historical events such as dealing with the consequences of World War II and later with rapid globalization. Takemura (2020) suggests that the Japanese are often confident and determined when the conditions are stable; but could become agitated and diffident when conditions change rapidly. He points out, however, that the Japanese people can also adapt quickly to changing conditions with fast-adjusting contingent responses. A valuable recommendation by the author may be that "if there is something other countries can 
learn from Japan, it is to create a new mode of everyday life and adapt to it, rather than expecting to return to everyday life before COVID-19 (p.9)."

\section{Normal as Fallible and Uncomfortable}

Some of the researchers, commentators and scenario-creating analysts commenting about the post-pandemic world have expressed the hope that it would be good - i.e., it would be familiar, comfortable, reassuring - if we could return to 'normal', or at least have some semblance of normalcy. At MGDR, as also recommended by Takemura (2020), we completely disagree and diverge from such viewpoints. There are strong reasons - from the perspective of this journal and its parent organization ISMD - to take this divergent position. A return-to-normal view - with its implied comfort level - assumes that the pre-pandemic state of affairs and state of the world were acceptable, even quite good. Re-achieving that state would be a mark of success.

We do not think the pre-pandemic state of the world was salutary, on many of the techno-economic, politico-cultural and socio-communal dimensions. Secondly, even if we grant some modicum of "goodness" to pre-pandemic conditions, a mere reverting to those conditions would imply that there is no need - at least no urgent need - for ideas and actions that could propel us to a world that could be significantly (orders of magnitude) better than the pre-pandemic world. A crucially important word in MGDR and ISMD is the ' $D$ ' word, Development. To us, development is a never-ending process. Many endorse such a view of development at the micro-individual level (ever more ambitious life goals, self-achievement targets, skills enhancement, etc.) and at the meso-organizational levels (higher targets, revenues, memberships, etc.), but reject it or shy away from it (with the exception of techno-economic aspects) at the macro - national, continental, global - levels. At MGDR, we do not shy away from seeking ideas and amelioration at the macro levels. We would continue to encourage articles, dialogues and reviews that seek better states-of-affair at the global (and, quite imminently, extra-global) levels - endorsing social equality and peace and environmental justice.

\section{Concluding Comments}

While we hope this will be the last editorial with an explicit focus on the COVID-19 pandemic, we can never be sure - since the evolving trajectory of the disease can bend in worse and tragic ways. What we are sure of is the commitment of MGDR and the parent group ISMD to the D-word: Development. We hope to continue to draw insightful and provocative contributions on the challenges and dilemmas - and opportunities and successes - of development efforts all over the world. 
Besides this journal, another good forum to test and discuss such ideas is the ISMD conference. The next one is being planned in Trichy, India, in December 2021 - with some physical sessions likely but mostly using remote and virtual formats of interacting. We hope all the MGDR readers will consider submitting to this conference by contacting the co-chair Hari Sreekumar (hari@iimtrichy.ac.in). 


\section{References}

Blumenthal, David, Eric C. Schneider, Shanoor Servai and Arnav Shah (2020), "3 Scenarios for How the Pandemic Could Change U.S. Health Care", Harvard Business Review, June 24, (accessed on September 22, 2020), [available at: https://hbr.org/2020/07/3-scenarios-for-how-the-pandemic-couldchange-u-s-health-care]

Cambefort, Marine (2020), "How the COVID-19 Pandemic is Challenging Consumption," Markets, Globalization \& Development Review, 5 (1), Article 2. https://doi.org/10.23860/MGDR-2020-05-01-02

Chikhi, Kamel (2020), "Consumption Behavior of Algerians During the Period of the Covid-19 Pandemic Crisis," Markets, Globalization \& Development Review, 5 (4), Article 4. https://doi.org/10.23860/MGDR-2020-05-04-04

Dholakia, Nikhilesh and Deniz Atik (2020a) "Rethink Everything 1: Markets, Globalization, Development," Markets, Globalization \& Development Review, 5 (1), Article 1. https://doi.org/10.23860/MGDR-2020-05-01-01

Dholakia, Nikhilesh and Deniz Atik (2020b) "Rethink Everything 2: Markets, Globalization, Development," Markets, Globalization \& Development Review, 5 (3), Article 1. https://doi.org/10.23860/MGDR-2020-05-03-01

Harwood, Tracy (2020), "Pandemic, Human Precarity and Post-Pandemic Metaverses," Markets, Globalization \& Development Review, 5 (4), Article 3. https://doi.org/10.23860/MGDR-2020-05-04-03

Lemos, Fernando, Thays do Nascimento, and Gustavo Dalmarco (2020), "Flexible and Autonomous Manufacturing Systems for Custom-Designed Products (FASTEN): An loT platform applied to Supply Chain Management in a Covid-19 Pandemic Scenario," Markets, Globalization \& Development Review, 5 (4), Article 2. https://doi.org/10.23860/MGDR-2020-05-04-02

Hong, Soonkwan (2020), "'Coronated' Consumption in the Viral Market," Markets, Globalization \& Development Review, 5 (1), Article 3. https://doi.org/10.23860/MGDR-2020-05-01-03

Karanfil, Gokcen (2020), "Michael Kwet, People's Tech for People's Power: A Guide to Digital Self Defense and Empowerment," Markets, Globalization \& Development Review, 5 (3), Article 4. https://doi.org/10.23860/MGDR-2020-05-03-04 
Kwet, Michael (2020), "Fixing Social Media: Toward a Socialist Digital Commons," Markets, Globalization \& Development Review, 5 (1), Article 4. https://doi.org/10.23860/MGDR-2020-05-01-04

Mason, Paul (2020), "Will Coronavirus Signal the End of Capitalism?," April 3, Al Jazeera, (accessed on June 21, 2020), [available at: https://www.aljazeera.com/indepth/opinion/coronavirus-signal-ca pitalism-200330092216678.html]

Mizukoshi, Kosuke and Yuichiro Hidaka (2020), "We Buy It to Aid: Japan's Aid Consumption during COVID-19," Markets, Globalization \& Development Review, 5 (3), Article 3. https://doi.org/10.23860/MGDR-2020-05-03-03

Neufeind, Max, Karl Adam, Jeremy Cliffe, Paul Jürgensen, Diego Rivas, Fabian Wigand, eds. (2020), What's at Stake: Our Societies after Corona - Six Scenarios for 2025, Berlin: Das Progressive Zentrum, ISBN: 978-3-96759-010-4.

Ozgun, Aras (2020), "Steven Soderbergh, Contagion (2011)," Markets, Globalization \& Development Review, 5 (1), Article 5. https://doi.org/10.23860/MGDR-2020-05-01-05

Takemura, Masaaki (2020), "Going Glocal in a Pandemic: Can Japan Offer Lessons for Others?" Markets, Globalization \& Development Review, 5 (4), Article 5. https://doi.org/10.23860/MGDR-2020-05-04-05

Ulusoy, Emre (2020), "Elysium as a Social Allegory: At the nexus of Dystopia, Cyberpunk, and Plutocracy," Markets, Globalization \& Development Review, 5 (3), Article 5. https://doi.org/10.23860/MGDR-2020-05-03-05

Vicdan, Handan (2020), "Platformization of COVID and the Rise of Biosocial Surveillance," Markets, Globalization \& Development $\begin{array}{llll}\text { Review, } & 5 & (3), & \text { Article }\end{array}$ https://doi.org/10.23860/MGDR-2020-05-03-02 